\title{
Serum lipid levels and body fat distribution in obese females
}

\author{
B. M. RIFKIND, MORNA GALE, AND I. D. JACKSON \\ From the Royal Infirmary, Glasgow
}

SYNOPSIS Serum triglyceride levels were significantly raised in 37 markedly obese females, especially in the younger subjects; cholesterol and phospholipid levels were normal. Considerable variation in triglyceride levels of equally obese subjects was observed.

No relationship was noted between triglyceride levels and the pattern of subcutaneous fat distribution. It is suggested that the high triglyceride levels of obese subjects may explain their predisposition to ischaemic heart disease.

Plasma triglyceride and, to a lesser extent, cholesterol levels are, in general, directly related to adiposity (Albrink and Meigs, 1964; Rifkind and Begg, 1966). The relationship, however, is complex in that although most subjects with hyperlipidaemia are obese, not all obese subjects maintain high lipid levels. These studies have been carried out on male subjects whose relative body weights have ranged widely. The present report is concerned with the plasma lipid levels of markedly obese females, and whether variation in the triglyceride levels of such subjects is related to different patterns of subcutaneous fat distribution as suggested by Albrink and Meigs (1964).

\section{MATERIALS AND METHODS}

Thirty-seven healthy obese female subjects were studied. All exceeded $130 \%$ of their standard weight, uncorrected for age, as calculated from the tables of Kemsley, Billewicz, and Thomson (1962). Although these tables relate to subjects aged 20 years and over, for the purposes of the present study, we have also used them to calculate the relative body weight of the younger subjects since this procedure merely underestimates the extent of their body fatness, which increases with age.

The subjects were seen, in the morning, having fasted overnight, and a venous blood sample was obtained. Levels of the following lipids were estimated in the blood samples: serum cholesterol by the AutoAnalyzer using a ferric chloride technique (Technicon AutoAnalyzer method N-24p); serum triglyceride by the method of Van Handel and Zilversmit (1957); and serum phospholipid by the method of Bartlett (1959).

The subcutaneous fat distribution of each subject was assessed by measuring her skinfold thickness at the three

Received for publication 8 November 1966. sites, ulnar, triceps, and subscapular, described by Albrink and Meigs (1964), except that the left side was used following the usual convention (Tanner and Whitehouse, 1962). Harpenden constant-pressure skinfold calipers were used following the technique described by Tanner and Whitehouse (1962).

The data obtained by use of this instrument were converted to a Gaussian distribution by use of the transforms of Edwards, Hammond, Healy, Tanner, and Whitehouse (1955) which were applied to the individual measurements. All skinfold measurements were carried out by the same observer.

Serum lipid levels were estimated in 37 healthy, fasting women who were not obese.

\section{RESULTS}

Plasma lipid levels have a log-normal distribution in the population (Carlson, 1960; Walton and Scott, 1964), and in the various statistical calculations the logarithms ${ }_{10}$ of the individual lipid levels were used; the results obtained for the means and standard deviation of each group were then reconverted, using antilogs, to an arithmetic and skewed distribution, which is described by its mean and by two values for one standard deviation above and below the mean. Similarly the transforms used in the calculations of the skinfold data were reconverted to an arithmetic scale.

The serum cholesterol, triglyceride, and phospholipid levels of the obese and control subjects are presented in Tables I, II, and III. Serum triglyceride levels were considerably and significantly elevated in the two younger decades of obese subjects. They were also higher in the 30-39 age group but did not differ significantly from the corresponding results of the controls. The serum triglyceride levels of the 
TABLE I

CHOLESTEROL LEVELS (mg./100 ml.) OF OBESE AND NONOBESE FEMALES

\begin{tabular}{lllll} 
& Age & & \\
\cline { 2 - 5 } & $10-19$ & $20-29$ & $30-39$ & $40-49$ \\
\hline Obese (A) & $170_{-35}^{+44}$ & $214_{-48}^{+61}$ & $209_{-40}^{+48}$ & $219_{-39}^{+46}$ \\
& $(7)^{1}$ & $(8)$ & $(14)$ & $(8)$
\end{tabular}

Non-obese (B)

\begin{tabular}{|c|c|c|}
\hline $\begin{array}{l}196_{-35}^{+55} \\
(10)^{-37}\end{array}$ & $\begin{array}{l}195^{+43} \\
(18)\end{array}$ & $\begin{array}{l}275_{-54}^{+68} \\
(8)\end{array}$ \\
\hline
\end{tabular}

Significance (A)-(B) $\quad p=0.1 \quad>0.1 \quad<0.02$

'Figures in parentheses refer to number of subjects studied. Results are the means and standard deviations.

\section{TABLE II}

TRIGLYCERIDE LEVELS (mg./100 ml.) OF OBESE AND NONOBESE FEMALES

\begin{tabular}{lllll} 
& \multicolumn{3}{l}{ Age } & \\
\cline { 2 - 5 } & $10-19$ & $20-29$ & $30-39$ & $40-49$ \\
\hline Obese (A) & $102_{-21}^{+27}$ & $100_{-37}^{+59}$ & $106_{-33}^{+47}$ & $96_{-27}^{+36}$ \\
& $(7)^{1}$ & $(8)$ & $(14)$ & $(8)$
\end{tabular}

Non-obese (B)

$\begin{array}{ccc}56_{-12}^{+15} & 58_{-9}^{+27} & 87+51 \\ (10) & (20) & (8)\end{array}$

Significance (A)-(B) $\quad p=<0.001<0.001 \quad>0.2 \quad-$

Figures in parentheses refer to number of subjects studied. Results are the means and stagdard deviations.

TABLE III

PHOSPHOLIPID LEVELS (mg./100 ml.) OF OBESE AND NONOBESE FEMALES

\begin{tabular}{|c|c|c|c|c|}
\hline & \multicolumn{4}{|l|}{ Age } \\
\hline & $1 \overline{10-19}$ & $20-29$ & $30-39$ & $40-49$ \\
\hline Obese (A) & $\begin{array}{l}204^{+53}-42 \\
(7)^{1}\end{array}$ & $\begin{array}{l}219_{-31}^{+36} \\
(8)\end{array}$ & $\begin{array}{l}229+114 \\
-78 \\
(14)\end{array}$ & $\begin{array}{l}229+59 \\
(8)-40\end{array}$ \\
\hline
\end{tabular}

Non-obese (B)

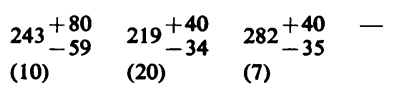

Significance (A)-(B) $\quad p>0.1 \quad>0.1 \quad>0.1$

${ }^{1}$ Figures in parentheses refer to number of subjects studied. Results are the means and standard deviations. obese subjects showed little tendency to rise with age, but those of the control group did.

No significant differences were noted between the groups with respect to cholesterol and phospholipid levels, except in the 30-39 age group in which the cholesterol levels of the controls were significantly higher. However, inspection of the data for the younger control subjects showed the cholesterol level of the 30-39 age group to be unusually high and it may be accounted for by a chance error of sampling.

To test out the hypothesis of Albrink and Meigs (1964) that triglyceride levels in obese subjects are related to body fat distribution, the obese subjects were divided into two groups, according to whether their serum triglyceride levels were below or equal to and above $100 \mathrm{mg} . / 100 \mathrm{ml}$. (Table IV). The mean triglyceride level of the first group was considerably and significantly lower than the second. The groups were closely matched in numbers, age distribution, and relative body weight. No significant differences were noted between them with respect to cholesterol or phospholipid levels. Their corresponding triceps, ulnar and subscapular skinfold thicknesses were similar nor did their subscapular/ulnar skinfold thickness ratio vary significantly, this ratio being taken as an index of the relative amounts of subcutaneous fat in the extremities and trunk.

\section{DISCUSSION}

In normal men and in those with peripheral vascular disease, a significant moderate positive correlation has been observed between body fatness, expressed as relative body weight, and plasma triglyceride levels. Less striking correlations have been noted between cholesterol and beta-lipoprotein levels with adiposity (Albrink and Meigs, 1964; Rifkind and Begg, 1966).

The present findings are in keeping with those observations in that, taken as a group, the obese

TABLE IV

COMPARISON OF SKINFOLD THICKNESSES OF OBESE FEMALES WITH TRIGLYCERIDE LEVELS $<100 \mathrm{mg}$. $/ 100 \mathrm{ml}$. (GROUP A) and $>100 \mathrm{mg}$. $/ 100 \mathrm{ml}$. (GROUP B)

\begin{tabular}{|c|c|c|c|c|c|c|c|c|}
\hline Group & $\begin{array}{l}\text { No. of } \\
\text { Subjects }\end{array}$ & $\begin{array}{l}\text { Triglyceride } \\
(\mathrm{mg} .1100 \mathrm{ml} .)\end{array}$ & $\begin{array}{l}\text { Relative Weight } \\
\text { (\% standard } \\
\text { weight) }\end{array}$ & $\begin{array}{l}\text { Age } \\
\text { (years) }\end{array}$ & $\begin{array}{l}\text { Ulnar Fold } \\
\text { (mm.) }\end{array}$ & $\begin{array}{l}\text { Triceps Fold } \\
(\mathrm{mm} .)\end{array}$ & $\begin{array}{l}\text { Subscapular } \\
\text { Fold (mm.) }\end{array}$ & $\begin{array}{l}\text { Ratio } \\
\text { Subscapu- } \\
\text { lar/Ulnar } \\
\text { Folds }\end{array}$ \\
\hline $\mathbf{A}$ & 19 & $\begin{array}{r}79+17 \\
-13\end{array}$ & $182 \pm 19$ & $33 \pm 12$ & $\begin{array}{r}10 \cdot 7_{-3.0}^{+4.6}\end{array}$ & $\begin{array}{r}24 \cdot 7+2 \cdot 8 \\
-2 \cdot 5\end{array}$ & $\begin{array}{r}26 \cdot 4^{+4.9} \\
-4 \cdot 1\end{array}$ & $1 \cdot 23 \pm 0 \cdot 1$ \\
\hline $\mathbf{B}$ & 16 & $\begin{array}{r}138_{-28}^{+36} \\
-28\end{array}$ & $177 \pm 16$ & $34 \pm 11$ & $\begin{array}{r}9 \cdot 7^{+3.6} \\
-2 \cdot 4\end{array}$ & $\begin{array}{r}25 \cdot 8+3 \cdot 5 \\
-3 \cdot 1\end{array}$ & $\begin{array}{r}25 \cdot 8+4 \cdot 2 \\
-3 \cdot 6\end{array}$ & $1 \cdot 27 \pm 0 \cdot 1$ \\
\hline Significance A-B & & $p<0.001$ & $>0.1$ & $>0.1$ & $>0.1$ & $>0.1$ & $>0.1$ & $>0.1$ \\
\hline
\end{tabular}

${ }^{1}$ Results as mean and standard deviations. 
female subjects had higher triglyceride levels than the control subjects. Serum cholesterol and phospholipid levels, however, were not significantly altered. The greatest differences between obese and nonobese were found in the younger subjects, reflecting the rise in triglyceride levels of the non-obese subjects with age, there being little variation in those of the obese subjects. Waxler and Craig (1964) have reported similar findings. The tendency for body fatness to increase with age may explain the rising triglyceride levels of the non-obese subjects. Significant correlations between relative body weight and lipid levels were not observed in the obese subjects, but this is not inconsistent with the correlations noted in the previous studies since they were derived from observations on large numbers of subjects with a wide range of relative body weight whilst the present study was carried out on an extremely obese group of subjects who, on the basis of results of the previous studies, might be expected to show considerable variation in lipid levels.

Both Albrink and Meigs (1964) and Rifkind and Begg (1966) found that in men, although hyperlipidaemia was usually associated with high relative body weight, not all obese subjects were hyperlipidaemic. Considerable variation in the triglyceride levels of the obese female subjects, unrelated to their degree of fatness, was also noted in the present study. This is illustrated in Table IV, which shows that, although the mean triglyceride levels of the two groups differed substantially, their mean relative body weights were similar. Albrink and Meigs (1964) suggested that obese subjects with high triglyceride levels were cases of acquired obesity, characterized by predominant accumulation of subcutaneous fat in the trunk with a relative sparing of the limbs, and that those subjects with low triglyceride levels were examples of congenital obesity with accumulation of fat both in the trunk and in the extremities. We have been unable to confirm that variation in triglyceride levels in obese female subjects is a function of the distribution of body fat. Since isocaloric substitution of dietary starch by sucrose leads to rises in plasma lipid levels, especially triglycerides (McDonald and Braithwaite, 1964), it is possible that the variation in the triglyceride levels of obese subjects is due to different sources of carbohydrate calories.

There have been several reports of high triglyceride levels in subjects who have had a myocardial infarction (Antonis and Bersohn, 1960; Schrade, Boehle, and Biegler, 1960). The high triglyceride levels observed in the present study may explain the predisposition of these subjects to develop various manifestations of ischaemic heart disease (Dawber, Kannel, and McNamara, 1964).

We are grateful to Professor E. M. McGirr for laboratory facilities and to Imperial Chemical Industries Limited for financial support.

\section{REFERENCES}

Albrink, M. J., and Meigs, J. W. (1964). Amer. J. clin. Nutr., 15, 255. Antonis, A., and Bersohn, I. (1960). Lancet, 1, 998.

Bartlett, G. R. (1959). J. biol. Chem., 234, 466.

Carlson, L. A. (1960). Acta med. scand., 167, 377.

Dawber, T. R., Kannel, W. B., and McNamara, P. M. (1964). Trans. Ass. Life Insur. med. Dir. Amer., 47, 70.

Edwards, D. A. W., Hammond, W. H., Healy, M. J. R., Tanner, J. M., and Whitehouse, R. H. (1955). Brit. J. Nutr., 9, 133.

Kemsley, W. F. F., Billewicz, W. Z., and Thomson, A. M. (1962). Brit. J. prev. soc. Med., 16, 189.

McDonald, I., and Braithwaite, D. M. (1964). Clin. Sci., 27, 23.

Rifkind, B. M., and Begg, T. B. (1966). Brit. med. J., 2, 208.

Schrade, W., Boehle, E., and Biegler, R. (1960). Lancet, 2, 1409.

Tanner, J. M., and Whitehouse, R. H. (1962). Brit. med. J., 1, 446.

Van Handel, E., and Zilversmit, D. B. (1957). J. Lab. clin. Med., 50, 152.

Walton, K. W., and Scott, P. J. (1964). J. clin. Path., 17, 627.

Waxler, S. H., and Craig, L. S. (1964). Amer. J. clin. Nutr., 14, 128. 